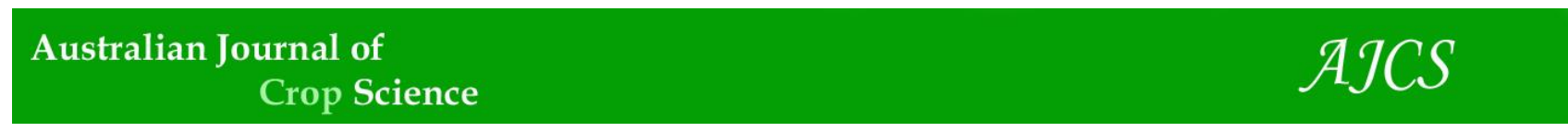

AJCS 10(6):784-792 (2016)

ISSN:1835-2707

DOI:10.21475/ajcs.2016.10.06.p7223

\title{
Morphometric analysis of mango varieties in Sri Lanka
}

\author{
N. Krishnapillai ${ }^{1 *}$ and R. S. Wilson Wijeratnam ${ }^{2}$ \\ ${ }^{1}$ Department of Botany, University of Jaffna, Jaffna, Sri Lanka and Postgraduate Institute of Science, University \\ of Peradeniya, Peradeniya, Sri Lanka \\ ${ }^{2}$ Industrial Technology Institute, 363, Bauddhaloka Mawatha, Colombo 7, Sri Lanka
}

*Corresponding author: nahmagal@gmail.com

\begin{abstract}
Mango is an important dry zone fruit crop in Sri Lanka. Mangoes grown in northern Sri Lanka show rich varietal diversity and have greater consumer demand compared with those from other regions of the country. In this study, eighteen mango varieties including 54 accessions from Jaffna were examined to evaluate morphological variations and determine fruit quality. A total of 46 morphological traits from IPBGR descriptors for mango were measured in 54 mango accessions between years 2009 and 2012. Qualitative and quantitative morphological traits including leaf, inflorescence and fruit characteristics were evaluated in the field as well as in the laboratory. High variation among the mango varieties was observed with respect to qualitative data such as colour of immature leaves, leaf shape, inflorescence axis flower colour, type of flower, fruit shape skin colour and texture. Collected quantitative data was subjected to principal component analysis (PCA) and hierarchical cluster analysis (HCA). PCA showed that first 4 principal component had $75.6 \%$ of the total variation. PC1 explained $34.2 \%$ variations and these components were fruit length, breadth, thickness and weight. Besides these parameters, seed and leaf length also showed high variation. PC2 showed $21.8 \%$ variations with the parameters of leaf length, leaf breadth and inflorescence length. Thus based on these variations and similarities in morphological traits, mango varieties were grouped into three by HCA. These PCA and HCA results suggest that broad morphologic diversity was found in mango varieties examined in this study. Over all fruit quality was measured by a trained taste panel. Fruit quality was rated excellent in 8 varieties with pink or red mixed attractive fruit skin or waxy yellow colour skin. Among the 18 mango varieties thus identified from the 54 accessions, 4 varieties were found to be exotic and 14 varieties were endemic to Sri Lanka.
\end{abstract}

Keywords: Morphological traits, mango varieties, PCA, HCA and fruit characters.

Abbreviations: IPBGR _ International Board for Plant Genetic Resources; PCA_Principal component analysis; HCA _ Hierarchical cluster analysis; IPGRI _ International Plant Genetic Resources Institute; CV__ Coefficient of variation; PC_ Principle component; w_ Willard; a_ Ambalavi; s_ Selam; K_ Karuthakolumban; c_ Chembaddan; ko_ Kodima; vk_ Vellaikolumban; m_ Malgoa; mt _ Maththalamthaddy; n _ Neelam; pe_Peterpasand; pn_Pandy; u_Unknown; pu_Pulima; P_ Pachchaithinni; va_ Vairakkandy; ki_Kilichondan; ka_Kalaikaddy.

\section{Introduction:}

The Mango (Mangifera indica L.) is an important fruit crop in Sri Lanka. It belongs to the family Anacardiaceae and order Sapindales. The mango tree is believed to have evolved as a canopy layer or emergent species in the tropical rain forests of south and south-east Asia (Kaur et al., 1980; Bompard, 2009). There are many varieties of mangoes. Each variety produces fruits of distinctive appearance, texture, flavour, and aroma. The yield capacity of a tree is dependent on variety, tree age, tree size, seasonal conditions and previous cropping history. Mango trees are long lived and expected to survive more than 100 years (Bally, 2006). ). The long period of domestic cultivation, cross-pollination nature, alloploidy and out-crossing have contributed to the wide genetic diversity in mangoes (Krishna and Singh, 2007; Mukherjee, 1972). In addition open pollination between the cultivars could have resulted in the appearance of new varieties (Ravishankar et al., 2000). Accordingly a rich diversity of mango varieties may be observed in the northern province of Sri Lanka where mango production is mostly at home garden level. As seedling varieties occur almost throughout the Jaffna district, the nomenclature for mango varieties thus remains a challenging task, particularly in circumstances where nomenclature with many synonyms exist for the same variety. In order to realize the potential for expanding the mango industry in Sri Lanka it is necessary to increase production of good quality mangoes and extend the period of availability of this seasonal crop to meet requirements of both domestic and export markets. Thus the identification of mango varieties with quality traits that will serve this purpose is an urgent necessity. Traditional classification of the genus Mangifera has been based on phenological and morphological characteristics of flowers, leave, fruits and seed and is a very useful low cost tool for local mango growers. Several procedures for the identification and characterization of mango genotypes have been developed based on outstanding morphological characters of fruits. Morphological variations of mango varieties have been studied extensively (Singh, 1960; Watson and Winston, 1984; Uddin et al., 2006 and 2007; Galvez Lopez et al., 2010; Rajwana 2011; Barua et al., 2013; Toili et al., 2013 Ribeiro et al., 2013; Mhamed and Ahmed, 2015). Detailed descriptions of mango cultivars are available 
in the publications of Knight et al. (2009), Naik and Gangolly (1950) for south Indian mangoes, Singh and Singh (1956) for Uttar Pradesh mangoes, Mukherjee (1948) for Bengal mangoes, Sam-Aggrey and Abutiate (1973) for Ghana mangoes and Campbell (1992) for Florida mangoes. A universally accepted procedure has been developed for characterization of mango varieties by the International Plant Genetic Resources Institute (IPGRI). The IPGRI has established a universal format of list of descriptors for mango that includes the morphological traits of plant, leaves, flowers, seeds and fruits (IBPGR, 1989, IPGRI, 2006). However, there remains a paucity of published information on characterization of mango varieties indigenous to Sri Lanka. Thus the aims of this study were firstly to identify and characterize mango varieties by using morphological traits (IBPGR, 1989, IPGRI, 2006) and secondly to determine diversity in mango germplasms and provide useful descriptors of mango varieties to mango growers, breeders and researchers.

\section{Results}

Mango varieties identified in Thirunelvely, Valikamam, and Vadamarachchi area of Northern Province were 11, 07 and 13 respectively (Table 1). Among the varieties identified Neelam, Peterpasand and Malgoa were introduced to the Department of Agriculture Farm, in Thirunelvely. These varieties did not perform well and production was low during the period of this study in 2009 and subsequently in the years 2010 to 2011. However, quantitative and qualitative morphological evaluation was conducted using all 54 accessions and the genetic relationship between varieties was established using cluster analysis.

\section{Leaf and inflorescence trait evaluation}

Most of the mango varieties showed spreading growth IPGRI habit with lanceolate leaf shape, acuminate leaf tip and entire leaf margin. Dark green colour mature leaves were observed in $80 \%$ of the trees where $82 \%$ of the leaves had strong fragrance. Colour of young leaves was selected as one of the important morphological traits for varietal characterization as high variation among the varieties was observed indicating 6 phenotypic classes (Table 2). The terminal position of inflorescence was a dominant morphological trait of compared to the axillary position. Inflorescence and flower colour varied from 2006 and it showed higher variation among the varieties. IPGRI Hexamerous type of flower was observed in 3 accessions which was not indicated in the 2006 . Inflorescence colour and flower type were selected to identify mango varieties (Table 2).

\section{Fruit quality traits}

Skin colour of ripe mango fruit varied from light yellow to orange while 10 accessions showed pink or red mixed skin colour. Fruits were observed to be oblong in 31 mango accessions and beak was absent in 16 accessions. Stem end cavity was not observed in 46 accessions and round apex was found in 49 mango accessions. Seeds were oblong with elevated forked venation in more than 35 accessions. Fruit traits of skin colour, shape, beak and stem end cavity showed clear variations and these traits were selected for further characterization of mangoes. Among the 54 accessions studied, 49 had high productivity, 36 showed excellent eating quality and 19 were observed to have attractive skin colour (Table 3).

\section{Principal component analysis (Eigen analysis of the} Correlation Matrix) of morphometric characters

Variations in parameters are presented in Table 4. Minimum coefficient of variation (9.07) was observed in flower diameter showing maximum percentage similarities among the mango varieties. High variations in fruit weight were reflected in the high Coefficient of variation (CV) of 37.23 as seen in Table 4. Fruit weight, fruit length and breadth were high in Maththalamthaddy $(948.5 \mathrm{~g}, \quad 19.8$ \& $16.6 \mathrm{~cm}$ respectively) while longest inflorescence $(43 \mathrm{~cm})$ was noted in Kilichondan. The most significant traits were fruit characteristics and all significant morphological traits were positively associated with the morphological variability of mango varieties (Table 5). The first four principle components explained $75.6 \%$ of total variation observed in the 18 mango varieties. PC1 explained $34.2 \%$ variations while PC2 explained $21.8 \%$ variation. PC1 loadings included fruit length, fruit breadth and fruit weight respectively. Variations of the parameters of leaf length, leaf breadth and inflorescence length were explained by PC2.

\section{Cluster analysis}

PCA and HCA showed similar groupings of mango varieties based on morphological traits (Fig 2 \& 3). Three clusters were observed. Maththalamthaddy (mt) alone formed one cluster since it had highest fruit weight. Varieties Ambalvi (a), Karuthakolumban (K), Pandy (pn), Selam (s), Kodima (ko), Malgoa (m), Unknown (u), Kilichondan (ki) were clustered together and showed higher weight compared to the third cluster. Most of the varieties in this cluster were oblong with the exception of Kodima and Malgoa. In third cluster roundish fruits were grouped together except for Chembaddan and Vellaikolumban.

\section{Fruit quality evaluation}

Fruit quality and biochemical evaluation were performed for the selected 18 mango varieties (Table 6). Highest Brix value (24.6) was observed in Kodima and lowest $\mathrm{pH}$ (5.45) was noted in Kilichondan. Overall fruit quality was excellent in 8 mango varieties. The shelf life of Selam and Karuthakolumban at ambient storage of $28^{\circ} \mathrm{C} \pm 2{ }^{\circ} \mathrm{C}$ was 9 days while maximum shelf life (10) was observed in Unknown mango variety (Table 6).

\section{Discussion}

This is the first taxonomic study regarding mango varieties in northern Sri Lanka, where high quality mangoes have been grown for many years. In this study 18 mango varieties were identified from three different locations based on characterization studies using IPGRI, 2006 alongside evaluation of data collected from growers via questionnaires and interviews. Among the 18 varieties identified, 4 varieties (Neelam, Malgoa, Selam and Peterpasand) were found to be exotic and 14 mango varieties endemic to Sri Lanka. All mango varieties were observed to be propagated by grafting, except the unknown variety mango from Vadamarachchi. Vadamarachchi area showed higher varietal variation and 13 mango varieties were identified in this area (Table 1). Mango varieties were characterized using 46 morphological traits. More than 4 phenotypic classes were observed in the 
Table 1. Identified mango varieties in three different areas of Jaffna and accession numbers used in this study.

\begin{tabular}{|c|c|c|c|}
\hline \multirow[t]{2}{*}{ Mango Varieties } & \multicolumn{3}{|c|}{ Accession numbers for different areas } \\
\hline & $\begin{array}{l}\text { Thirunelvely } \\
\text { Agriculture farm }\end{array}$ & Valikamam & **Vadamarachchi \\
\hline Willard & $(\mathrm{w} 1, \mathrm{w} 2, \mathrm{w} 3)$ & $(\mathrm{w} 4, \mathrm{w} 5, \mathrm{w} 6)$ & $(\mathrm{w} 7, \mathrm{w} 8, \mathrm{w} 9)$ \\
\hline Ambalavi & $(\mathrm{a} 1, \mathrm{a} 2, \mathrm{a} 3)$ & $(\mathrm{a} 4, \mathrm{a} 5, \mathrm{a} 6)$ & $(\mathrm{a} 7, \mathrm{a} 8, \mathrm{a} 9)$ \\
\hline Karuthakolumban & $(\mathrm{K} 1, \mathrm{~K} 2, \mathrm{~K} 3)$ & $(\mathrm{K} 4, \mathrm{~K} 5, \mathrm{~K} 6)$ & $(\mathrm{K} 7, \mathrm{~K} 8, \mathrm{~K} 9)$ \\
\hline Chembaddan & (c1) & $(\mathrm{c} 2)$ & $(\mathrm{c} 3, \mathrm{c} 4, \mathrm{c} 5)$ \\
\hline Selam & (s1) & $(\mathrm{s} 2)$ & $(\mathrm{s} 3, \mathrm{~s} 4, \mathrm{~s} 5)$ \\
\hline *Kodima & $*(\mathrm{ko} 1)$ & _- & (ko2, ko3) \\
\hline *Vellaikolumban & $*(\mathrm{vk} 1)$ & _- & (vk) \\
\hline Malgoa & $* *(\mathrm{~m} 1, \mathrm{~m} 2)$ & - & - \\
\hline Maththalamthaddy & $* *(\mathrm{mt})$ & - & - \\
\hline Neelam & $* *(\mathrm{n})$ & - & - \\
\hline Peterpasand & $* *(\mathrm{pe})$ & - & - \\
\hline Pandy & - & $(\mathrm{pn} 1)$ & $(\mathrm{pn} 2)$ \\
\hline **Kalaikaddy & - & $* *(\mathrm{ka})$ & - \\
\hline Unknown & - & - & (u) \\
\hline Pulima & _- & _- & $(\mathrm{pu})$ \\
\hline Pachchaithinni & - & - & $(\mathrm{P} 1, \mathrm{P} 2)$ \\
\hline Vairakkandy & _ & _ & (va) \\
\hline Kilichondan & _ & _- & (ki) \\
\hline
\end{tabular}

*Accessions were not included in the morphological evaluation since these trees were young; $* *$ Accessions were used for fruit quality evaluation; _ means varieties were not found in that area.

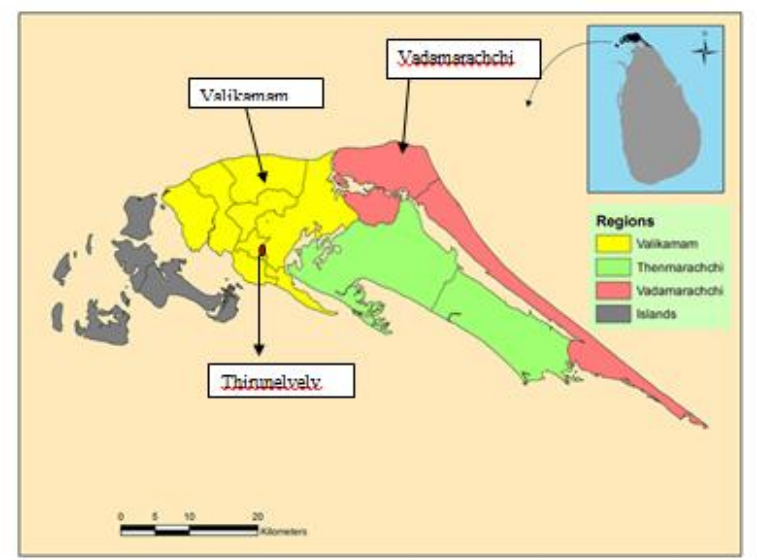

Fig 1. Schematic Map of selected study area in Jaffna district of Sri Lanka.(A) Thirunelvely; (B) Valikamam area; (C) Vadamarachchi area.

qualitative parameters of colour of young leaf, colour of inflorescence and flower, flower type, fruit skin colour, fruit shape, beak type and stem end cavity (Table 2 and 3). These variations were most significant in identifying mango varieties. Mangoes from Jaffna district are exceptional in taste and quality. Growth habit of 35 (64.8\%) mango accessions in this study were spreading and 49 accessions $(88.8 \%)$ showed high yield. Eating quality of 8 mango varieties was excellent. Only 10 mango accessions showed green to yellow skin colour while 44 accessions showed attractive skin colour. Willard and Kilichondan had attractive skin colour, with excellent fruit quality and were noted as suitable for export markets in Europe where red toned skin colour mangoes with sweet taste are preferred (Litz, 2009). Mature green Pandy, Pulima and Selam variety mangoes were suitable for processing while ripened Selam mango is acceptable as a dessert fruit. The remaining 15 mango varieties were suitable for both processing and consumption as table fruits. Important fruit quality parameters are shown in Table 6, where overall fruit quality is indicated as excellent in 8 varieties. Many of the mango industries in the larger producing nations are based on traditional mango cultivars that have been grown for hundreds of years (Bally, 2011). The Selam mango tree is a spreading, high yielding tree with regular bearing characteristics. Morphological descriptors of this mango showed a $100 \%$ match with the Bangalora variety described by Gangolly et al. in 1967 . The name Selam clearly indicates that this variety originated from India and this study confirms that Selam mango is the same as the Bangalora variety which was also introduced from India. 
Table 2. Summary of qualitative morphologic traits of tree, leaf and inflorescence (according to IBPGR 1989; IPGRI 2006, Now biodiversity international) measured in different mango germplasms. Numbers in brackets indicate the number of accessions per class.

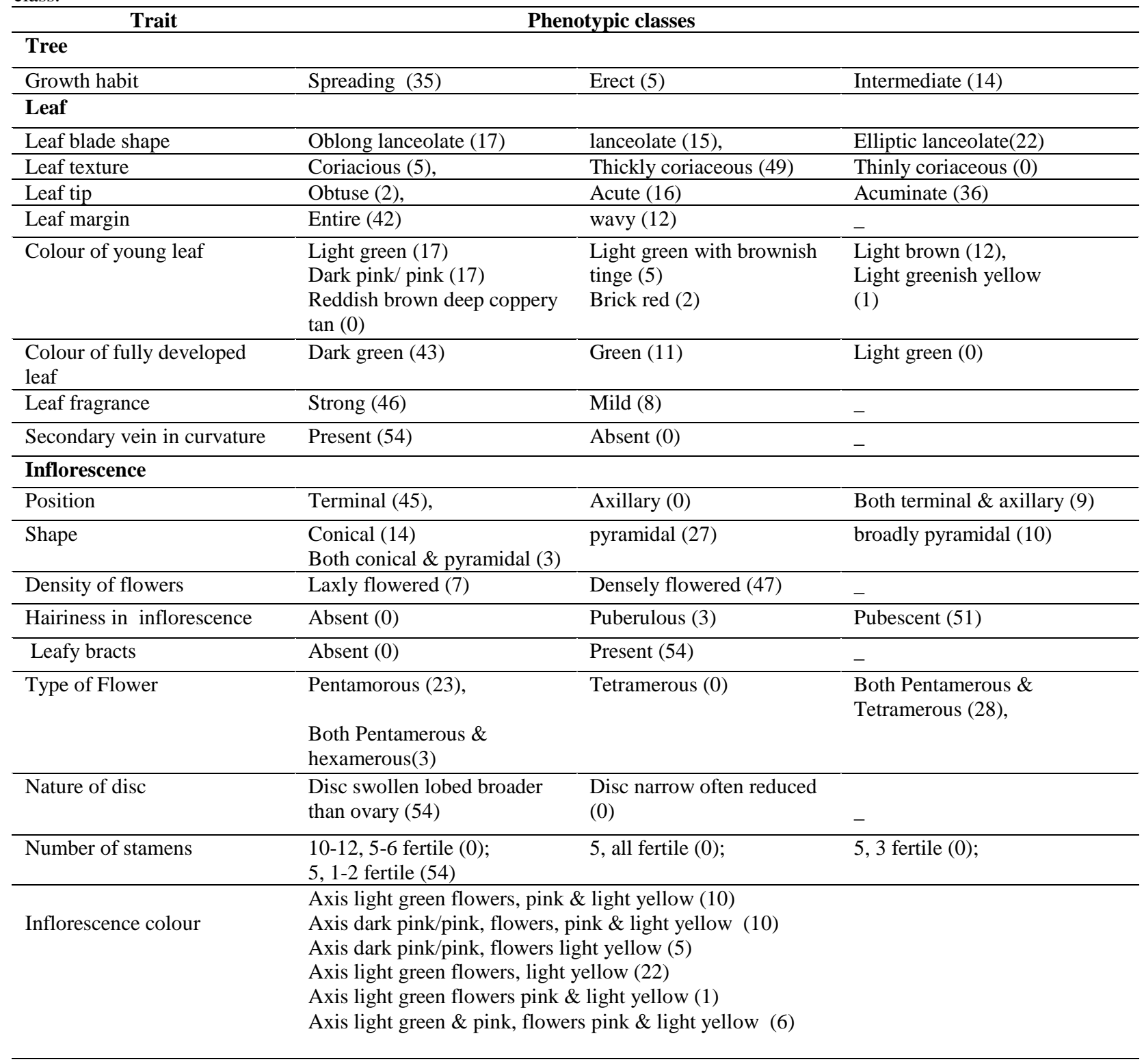

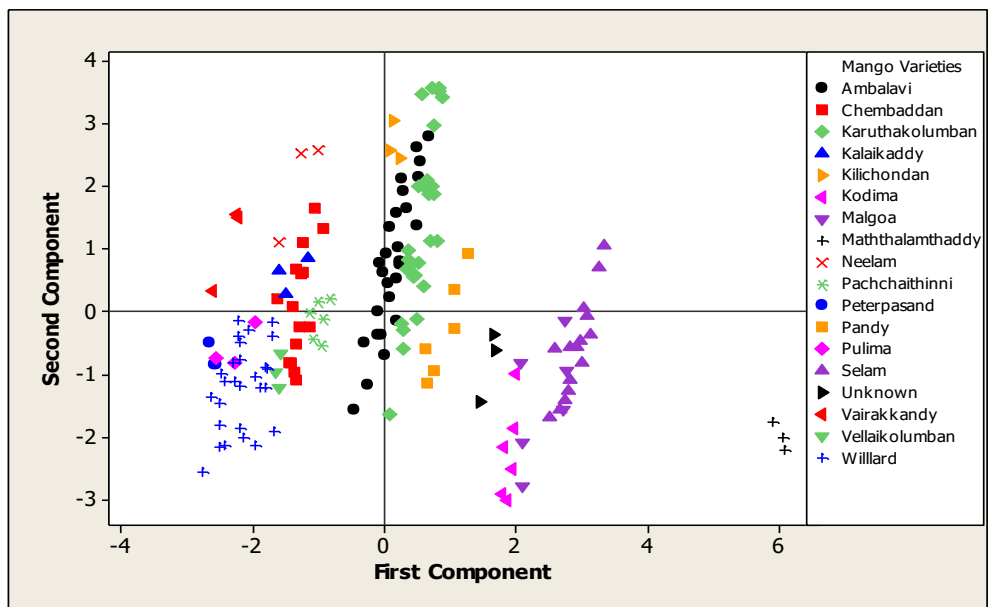

Fig 2. Dispersion of mango varieties based on PCA analysis of morphological data. PCA analysis of mango accessions showed that remarkable variation among the mango accessions surveyed and existence of greater mango diversity. The varieties scattered on the far right corner were characterized by high fruit weight while on the left side were varieties with low fruit weight. 
Diversity of mango cultivars in Sudan was studied by Mhamed and Ahmed (2015) based on leaf anatomy. Molecular technique is a useful tool in establishing cultivar identification and relationship based on morphological traits and fruit quality of mango varieties. The Sri Lankan Betti amba, Coconut, Rupee, Vellaikolumban and Willard were included in a study using the genetic diversity of the Australian mango gene pool. Based on phylogeny tree, these Sri Lankan varieties showed close relationship with Florida, Hawaii mangoes and mangoes from Australia and Caribbean (Dillion et al., 2013). Fruit quality is the result of interaction between environment and the genetic makeup of the mango crop. When environmental conditions are almost uniform as in the dry zones of Sri Lanka, morphological traits and fruit quality are observed only to be affected by genetic makeup of mango varieties. In this scenario morphological traits prove to be an efficient tool for varietal characterization in Sri Lanka. Data on morphological diversity of mango germplasm is vital for developing good quality mangoes with high yields. Variability among the 54 mango accessions were studied using Principal Component Analysis (PCA) and Hierarchical Cluster Analysis (HCA). The variation can be explained by the principle components and the correlation between principle components while original variables less than 0.25 can be discarded (Jolliffe, 1986). The 66.9\% variation was explained by the first three principle components which were selected due to the eigenvalue being higher than one. PC1, PC2 and PC3 contributed 34.2, 21.8 and $10.9 \%$ of the total variations. The $\%$ of variations was reduced successively and it was $8.8 \%$ in PC4. Fruit length $(0.52 \%)$, breadth $(0.47 \%)$ and fruit weight $(0.45 \%)$ were the major variables contributing to $\mathrm{PC} 1$ while leaf length (0.53), breadth (0.5) and inflorescence length (0.44) contributed more to the PC2 (Table 5). Galvex-Lopez et al. (2010) reported that fruit length, breadth, weight, thickness, leaf length and leaf breadth were used to index mango morphology. Toili et al (2012) studied morphological diversity of mango germplasms in the absence of fruits and they used tree and leaf characters. Morphological characterization of Kenya mangoes were reported by Sennhenn et al. (2011 and 2014). The study on morphological traits including fruit characters of 60 mango genotypes in Bangladesh showed that they had variations and gave opportunity to select germplasms on the basis of desirable characters (Majumder et al., 2011). The PCA biplot can be used to classify mango genotypes and visualize the relationship among the varieties. The distribution of mango accessions in the PCA based on the PC1 and PC2 showed the variations among the accessions. The varieties scattered on the far right corner were characterized by high fruit weight namely Maththalamthaddy; while on the left side were varieties with low fruit weight such as Willard, Chembaddan, Pulima, Pachchaithinni, Neelam, Peterpasand and Vellaikolumban. The remaining fruits with average weight were scattered in the centre of the PCA biplot (Fig 2). PCA of morphological traits of mango accessions in Nepal also showed greater genetic diversity (Subedi et al., 2005). Similar variables in PCA were used in HCA. Variability among 18 mango varieties was measured and classified using non weighted pair group method cluster analysis of correlation matrix, for quantitative data. Based on the variations and similarities of morphological traits, mango varieties were grouped into three by HCA. Only one mango variety Maththalamthaddy had the higher fruit weight and formed the first cluster. The second cluster was formed by 31 mango accessions together including Karuthakolumban, Ambalavi and Selam. Unknown mangoes were also in the second cluster and showed close relationship with the Pandy variety. Small, low weight fruits with 22 accessions formed the third cluster. Similar clusters of mango accessions based on fruit weight were recorded in Mozambique (Mussane et al., 2011). These PCA and HCA results suggest that broad morphologic diversity existed in the mango accessions collected in this study.

\section{Materials and Methods}

\section{Mango germplasm identification}

A survey was carried out to identify and locate different varieties of mangoes in Jaffna (Northern Province of Sri Lanka) via questionnaires and interviews. Three areas in Jaffna were selected for this study. Based on the results of the

\section{Evaluated characteristics}

Leaf characteristics - Three replicates of fully mature mango leaves from each variety were characterized for colour, fragrance strength, leaf blade shape, length and width, petiole length, leaf apex shape, leaf margin type, leaf texture, leaf pubescence and secondary vein in curvature. Colour of young leaves was observed in the field. Panicle characteristics Three replicates of fully developed inflorescences from each variety were used for characterization of panicles. Position, shape, colour, length and hairiness of inflorescence were evaluated. In addition density of flowers in the inflorescence, season of flowering, secondary flowering, flower diameter, type of flower, nature of disc and number of stamens was also evaluated. Fruit characteristics - Fruit weight, shape, skin colour, skin thickness and texture, flesh texture, content and fiber content, stalk insertion, beak, basal cavity, sinus, groove, shoulder forms, apex, stone length, stone weight, veins in stones, venation, fiber in stone, fruit attractiveness, eating quality were evaluated as fruit characters in ripened fruits. Total soluble solids and $\mathrm{pH}$ of mango juice were measured. The market acceptablity or overall quality of fruits was determined by the percentage of fruits which were suitable for marketing. Fruits with good external colour, appearance and minimum incidence of disease were subjected to taste panel (Krishnapillai, 1996).

\section{Statistical analysis}

Collected data was subjected to descriptive statistics (To list the minimum, maximum, mean, standard deviation and coefficient of variation), principal component analysis and cluster analysis by using Minitab release 15. Multivariate analysis both PCA and HCA (using group average linkage and squared Euclidian distance) were carried out in order to understand morphometric variation. Quality parameters such as Brix and $\mathrm{pH}$ were subjected to Analysis of variance and Tukey's test.

\section{Conclusion}

This study documented 18 mango varieties with the evaluation of fruit quality using mango descriptors list (IPGRI, 2006). Collected quantitative data was subjected to principal component analysis (PCA) and hierarchical cluster analysis (HCA). PCA showed that the first 4 principal components had $75.6 \%$ of the total variation. These components were fruit length, diameter, thickness and weight. Based on the variations and similarities of 
Table 3. Summary of qualitative morphologic traits of fruits, Seeds and varietal characters (according to IBPGR 1989; IPGRI 2006, Now biodiversity international) measured in different mango germplasms. Numbers in brackets indicate the number of accessions per class.

\begin{tabular}{|c|c|c|c|}
\hline \multirow{2}{*}{$\begin{array}{ll} & \text { Trait } \\
\text { Fruit } & \end{array}$} & \multicolumn{3}{|c|}{ Phenotypic classes } \\
\hline & & & \\
\hline \multirow{2}{*}{ Shape } & Oblong (31) & Elliptic (3) & Roundish (17) \\
\hline & Ovoid (0) & Obovoid (0) & Others (3) \\
\hline \multirow[t]{2}{*}{ Colour of the skin } & $\begin{array}{l}\text { Red or pink mixed with } \\
\text { yellow (10) }\end{array}$ & Dark Yellow (15) & Yellow/light yellow (10) \\
\hline & Yellow - Green yellow (10) & Orange (9) & \\
\hline $\begin{array}{l}\text { Thickness of fruit } \\
\text { skin }\end{array}$ & $\begin{array}{l}\text { Thin }(16) \\
\text { Very thick (1) }\end{array}$ & Medium thick (35) & Thick (2) \\
\hline Skin texture & Smooth (53) & rough (1) & $\ldots$ \\
\hline Pulp texture & Firm (39) & Soft (10) & Juicy (5) \\
\hline Fibre in pulp & Absent (0) & Present (54) & - \\
\hline Quantity of fibre & Scarce (30) & Abundant (24) & - \\
\hline Stalk insertion & Vertical (49) & Oblique (5) & - \\
\hline Shape of the fruit apex & Acute (2) & Obtuse (3) & $\begin{array}{l}\text { Round (49) } \\
\text { Other }(0)\end{array}$ \\
\hline Basal cavity & Absent (46) & Present (8) & \\
\hline $\begin{array}{l}\text { Beak type Absent (16) Minute point } \\
\text { (16) Point (16) Prominent (1) } \\
\text { Mammi form (5) }\end{array}$ & $\begin{array}{l}\text { Absent (16) } \\
\text { Prominent (1) }\end{array}$ & $\begin{array}{l}\text { Minute Point (16) } \\
\text { Mammi form (5) }\end{array}$ & Point (16) \\
\hline Sinus type & $\begin{array}{l}\text { Absent (16) } \\
\text { Deep (9) }\end{array}$ & Very narrow (10) & Shallow (19) \\
\hline Groove & Absent (26) & Present (28) & - \\
\hline Apex & Acute (2) & Obtuse (3) & Round (49) \\
\hline Shoulders & Level (10) & $\begin{array}{l}\text { Dorsal higher than ventral } \\
(42)\end{array}$ & $\begin{array}{l}\text { Ventral higher than } \\
\text { dorsal (2) }\end{array}$ \\
\hline Slope of the dorsal shoulders & Sloping abruptly (8) & $\begin{array}{l}\text { Ending in a long curve } \\
(32)\end{array}$ & $\begin{array}{l}\text { Rising and then } \\
\text { Rounded (14) }\end{array}$ \\
\hline \multicolumn{4}{|l|}{ Seed } \\
\hline Shape & Ellipsoid (0) & Oblong (40) & Reniform (14) \\
\hline Veins & Level with the surface (9) & Depressed (36) & Elevated (9) \\
\hline Pattern of venation & Parallel (19) & Forked (35) & \\
\hline Fibre & Absent $(0)$ & Present (54) & \\
\hline Quantity of stone fibre & Low (12) & Intermediate (30) & High (12) \\
\hline \multicolumn{4}{|l|}{ Cultivar/Varieties } \\
\hline Season of flowering & Early (20) & Intermediate (24) & Late (10) \\
\hline Productivity & Low (4) & Intermediate (1) & High (49) \\
\hline Eating Quality & $\begin{array}{l}\text { Excellent (36) } \\
\text { Poor }(0)\end{array}$ & Good (14) & Intermediate (4) \\
\hline Fruit attractiveness & $\begin{array}{l}\text { Excellent (19) } \\
\text { Poor (3) }\end{array}$ & Good (27) & Intermediate (5) \\
\hline
\end{tabular}

Table 4. Descriptive Statistics of quantitative morphological traits.

\begin{tabular}{|c|c|c|c|c|}
\hline Variable & Mean \pm SE & $\mathrm{CV}$ & Minimum & Maximum \\
\hline Leaf length $(\mathrm{cm})$ & $24.52 \pm 0.581$ & 17.42 & 17.30 & 35.7 \\
\hline Leaf breadth $(\mathrm{cm})$ & $5.27 \pm 0.169$ & 23.54 & 3.00 & 9.5 \\
\hline Petiole length $(\mathrm{cm})$ & $2.83 \pm 0.096$ & 24.92 & 1.60 & 4.3 \\
\hline Flower diameter $(\mathrm{cm})$ & $7.86 \pm 0.097$ & 9.07 & 6.90 & 9.1 \\
\hline \multicolumn{5}{|l|}{ Inflorescence } \\
\hline Length (cm) & $25.26 \pm 0.909$ & 26.44 & 13.00 & 43.0 \\
\hline Fruit length $(\mathrm{cm})$ & $13.05 \pm 0.400$ & 22.51 & 8.80 & 19.8 \\
\hline Fruit breadth $(\mathrm{cm})$ & $9.99 \pm 0.266$ & 19.53 & 7.00 & 16.6 \\
\hline Fruit weight (g) & $302.1 \pm 15.3$ & 37.23 & 199.0 & 948.5 \\
\hline Seed length $(\mathrm{cm})$ & $9.21 \pm 0.275$ & 21.92 & 4.20 & 11.9 \\
\hline Fruit thick $(\mathrm{cm})$ & $6.15 \pm 0.221$ & 26.35 & 4.00 & 9.7 \\
\hline
\end{tabular}




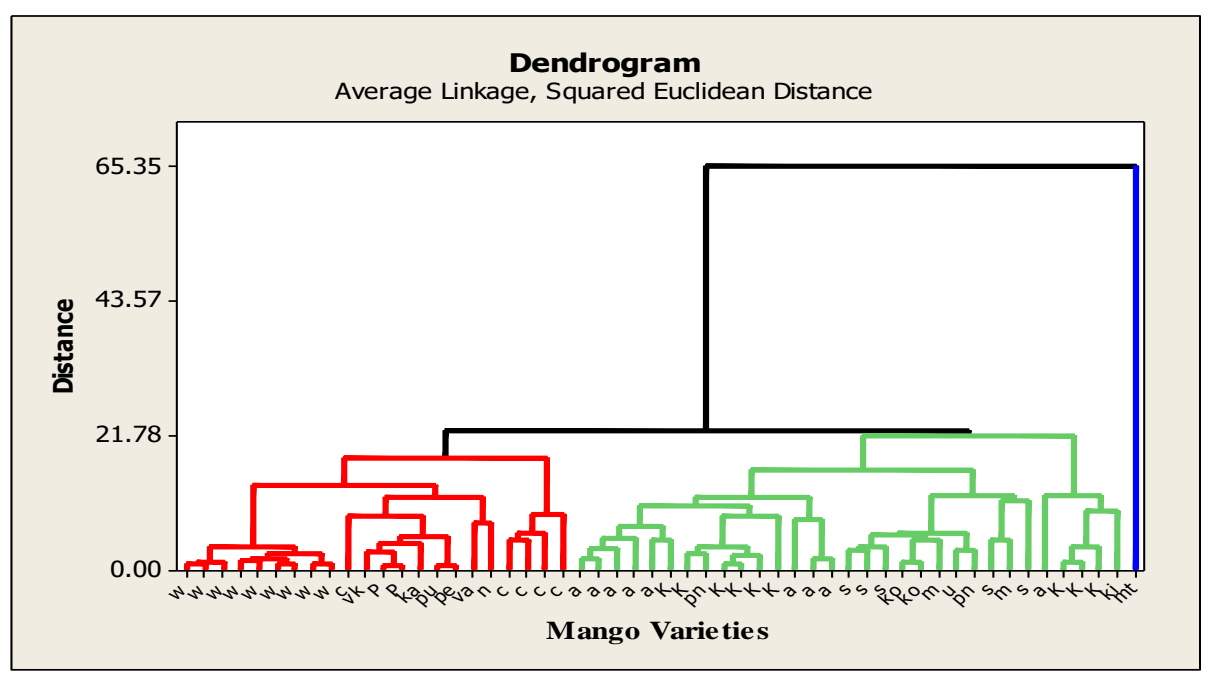

Fig 3. Dendrogram of 54 mango accessions based on quantitative morphological traits. (Blue colour - first cluster, green colour Second cluster, Red colour - third cluster; Accessions codes in table 3.1 were used here except numbers - alphabets only )

Table 5. Eigen vectors of *most descriptive traits measured in mango varieties.

\begin{tabular}{lllll}
\hline Variable & PC1 & PC2 & PC3 & PC4 \\
\hline Leaf length & 0.024 & $* 0.533$ & -0.042 & -0.268 \\
Leaf breadth & 0.157 & $* 0.508$ & -0.062 & -0.339 \\
Petiole length & 0.020 & 0.352 & -0.414 & $* 0.701$ \\
Flower diameter & -0.109 & -0.197 & -0.839 & -0.140 \\
Inflorescence length & 0.104 & $* 0.445$ & 0.028 & -0.094 \\
Fruit length & $* 0.521$ & -0.024 & -0.057 & -0.002 \\
Fruit breadth & $* 0.473$ & -0.120 & -0.252 & -0.223 \\
Fruit weight & $* 0.459$ & -0.192 & -0.061 & -0.156 \\
Seed length & $* 0.378$ & 0.123 & $* 0.104$ & 0.438 \\
Fruit thickness & $* 0.322$ & -0.174 & $* 0.194$ & 0.163 \\
Eigenvalue & 3.4249 & 2.1775 & 1.0853 & 0.8761 \\
Proportion & 0.342 & 0.218 & 0.109 & 0.088 \\
Cumulative proportion & 0.342 & 0.560 & 0.669 & 0.756 \\
Total Variance (\%) & 34.2 & 56.0 & 66.9 & 75.6 \\
\hline
\end{tabular}

Table 6. Biochemical and quality characteristic of mango germplasm after ripening (Means with the same letters along the column are not significantly different at $\mathrm{P}=0.05$ ).

\begin{tabular}{lcclcc}
\hline $\begin{array}{l}\text { Mango } \\
\text { Varieties }\end{array}$ & $\begin{array}{c}\text { TSS } \\
\left({ }^{\circ} \text { Brix }\right)\end{array}$ & $\mathrm{pH}$ & $\begin{array}{l}\text { Edible } \\
\text { portion\% }\end{array}$ & $\begin{array}{l}{ }^{\mathrm{a}} \text { SL } \\
\text { (Days) }\end{array}$ & $\begin{array}{c}\text { Overall } \\
\text { Quality }\end{array}$ \\
\hline Ambalavi & $22.3^{\mathrm{a}}$ & $5.03^{\mathrm{a}}$ & 75.2 & 8 & Excellent \\
Willard & $23.5^{\mathrm{h}}$ & $4.94^{\mathrm{d}}$ & 76.4 & 7 & Excellent \\
Karuthakolumban & $22.5^{\mathrm{a}}$ & $5.40^{\mathrm{b}}$ & 78.9 & 9 & Excellent \\
Chembaddan & $21.3^{\mathrm{b}}$ & $4.93^{\mathrm{a}}$ & 72.4 & 8 & Excellent \\
Selam & $16.7^{\mathrm{f}}$ & $4.80^{\mathrm{d}}$ & 74.2 & 9 & Very good \\
*Pandy & $12.2^{\mathrm{g}}$ & $4.17^{\mathrm{h}}$ & 75.9 & - & Very good \\
*Pulima & $13.0^{\mathrm{h}}$ & $4.03^{\mathrm{h}}$ & 73.2 & - & Very good \\
Kodima & $24.6^{\mathrm{d}}$ & $5.23^{\mathrm{g}}$ & 73.9 & 8 & Excellent \\
Vellaikolumban & $16.7^{\mathrm{f}}$ & $5.19^{\mathrm{g}}$ & 77.1 & 7 & Very good \\
Malgoa & $20.3^{\mathrm{e}}$ & $4.67^{\mathrm{d}}$ & 75.1 & 6 & Excellent \\
Pachchaithinni & $20.0^{\mathrm{e}}$ & $4.91^{\mathrm{a}}$ & 74.8 & 7 & Excellent \\
Kilichondan & $18.8^{\mathrm{c}}$ & $5.45^{\mathrm{b}}$ & 75.7 & 7 & Excellent \\
Kalaikaddy & $18.6^{\mathrm{c}}$ & $4.89^{\mathrm{d}}$ & 74.1 & 8 & Very good \\
Vairakkandy & $18.4^{\mathrm{c}}$ & $4.86^{\mathrm{d}}$ & 76.1 & 9 & Very good \\
Maththalamthaddy & $17.0^{\mathrm{f}}$ & $3.83^{\mathrm{e}}$ & 78.3 & 7 & Very good \\
Neelam & $17.1^{\mathrm{f}}$ & $4.50^{\mathrm{f}}$ & 75.2 & 7 & Very good \\
Peterpasand & $20.0^{\mathrm{e}}$ & $4.76^{\mathrm{d}}$ & 72.5 & 7 & Very good \\
Unknown & $16.9^{\mathrm{f}}$ & $4.91^{\mathrm{d}}$ & 73.2 & 10 & Very good
\end{tabular}

${ }^{\mathrm{a}} \mathrm{SL}-$ Storage life at ambient conditions $\left(28-34^{\circ} \mathrm{C} \& 65-80 \% \mathrm{RH}\right) *$ Storage life was not indicated. These two varieties are used as green mangoes for curry, chutney and green mango processing 
morphological traits, mango varieties were grouped into three categories by HCA. Fruit quality was excellent in 8 varieties with attractive fruit skin. Among the 18 mango varieties, four varieties were found to be exotic and 14 varieties were endemic to Sri Lanka. Conservation of this local mango gene pool is important for crop improvement.

\section{Acknowledgements}

National Research Council of Sri Lanka (Grant No: $\mathrm{NRC/07/72)} \mathrm{is} \mathrm{gratefully} \mathrm{acknowledged} \mathrm{for} \mathrm{financial}$ assistance.

\section{References}

Bally ISH (2006) Electronic Document Delivery - Mangifera indica (Mango), Anacardiaceae. Specific profiles for pacific Island Agroforestry, www.traditionaltree.org. Accessed on 18/10/2011.

Bally ISH (2011) Electronic Document Delivery - Advances in research and development of mango industry. Rev Bras Frutic. 33 http://www.scielo.br. Accessed on 09/08/2014.

Barua H, Alam Patwary MM, Rahman MH (2013) Performance of Bari mango (Mangifera indica L.) varieties in Chittagong region. Bangladesh J Agril Res. 38(2): 203209.

Bompard JM (2009) Taxonomy and systamatics. In: Litz RE (ed) The Mango Botany, Production and Uses. $2^{\text {nd }}$ edn. CAB International, UK. pp 19-41.

Campbell RJ (1992) A Guide to Mangoes in Florida, Miami Fairchild Tropical Garden. Florida.

Dillion NL, Bally ISE, Wright CL, Hucks L, Irries DJ, Dietzgen RG (2013) Genetic diversity of the Australian National Mango genebank. Sci Hortic-Amsterdam. 150: 213-226.

Galvez-Lopez D, Salvador-Figueroa M, Adriano-Anaya M and Mayek-Perez N (2010) Morphological characterization of native mangoes from Chiapas, Mexico. Subtrop Plant Sci. 62: 18-26.

Gangolly SR, Singh R, Katyal S and Singh D (1957) The Mango. A Hand book. Indian Council of Agricultural Research, New Delhi. pp 530.

International Board for Plant Genetic Resources (IBPGR) (1989) Descriptors for Mango. (Mangifera indica L.). International Plant Genetic Resources Institute, Rome, Italy. pp 22.

International Plant Genetic Resources Institute (IPGRI) (2006) Descriptors of Mango (Mangifera indica L.). International Plant Genetic Resources Institute, Rome, Italy. pp 60.

Jolliffe IT (1986) Principal components analysis, Springer, London. pp 487.

Kaur A, Ha CO, Jong K, Sands VE, Chan HT, Soepadmo E Ashton PS (1980) Apomixis may be widespread among trees of the climax rain forest. Nature. 271, 440-442.

Knight RJ, Campbell RJ, Maguire I (2009) Important mango cultivars and their descriptors. In : Litz RE (ed) The Mango Botany, Production and Uses. $2^{\text {nd }}$ edn. CAB International, UK.

Krishna H, Singh S (2007) Biotechnological advances in mango (Mangifera indica L.) and their future implication in crop improvement - A Review. Biotech Adv. 25, 223-243.

Krishnapillai N, Herath HMW and Wijetunga D (1996) Postharvest changes in three varieties of mango as affected by pre \& postharvest treatments. Tropic Agric Res. 8: 315326.
Litz R E (2009) The Mango. Botany, Production and uses. $2^{\text {nd }}$ edn. CAB international, Wallingford, USA. pp 680.

Mhamed ZMA, Ahmed THM (2015) Diversity of Mango (Mangifera indica L.) Cultivars in Shendi Area: Morphological Leaf Characterization. Int J Res Agric Sci. 2(4): 2348 - 3997.

Majumder DAN, Hassan L, Rahim MA Kabir MA (2011) Studies on physio-morphology, floral biology and fruit characteristics of mango. J Bangladesh Agri Univ. 9 (2):187-199.

Mukherjee SK. (1972) Origin of mango. Econ Bot. 26: 260 264.

Mussane CRB, Biljon AV, Herselman L (2011) Morphological and genetic characterization of mango varieties in Mozambique. African Crop Science Conference Proceedings, 10: $387-391$

Naik KC (1949) South Indian Fruits and their Culture. P. Varadachary and Company, Madras, India. pp 335.

Naik KC Gangolly SR (1950) A Monograph on Classification and Nomenclature of South Indian Mangoes. Government Press, Madras, India. pp 311.

Rajwana IA, Khan IA, Malik AU, Saleem BA, Kahn AS, Ziaf K, Anwar R Amin M (2011) Morphological and biochemical markers for varietal characterization and quality assessment of potential indigenous mango (Mangifera indica L.) Germplasm. Int J Agri Biol. 13:151158.

Ravishankar KV, Lalitha A, Dinesh MR Anand L (2000) Assessment of genetic relatedness among mango cultivars of India using RAPD markers. J Hortic Sci Biotech. 75(2):198201.

Ribeiro ICNS, Santos CAF, Neto FPL (2013) Morphological characterization of mango (Mangifera indica) accessions based on Brazilian adapted descriptors. J Agric Sci Technol. B3: 798-806.

Sam-Aggrey G, Abutiate WS (1973) Description of some mango cultivars in Ghana. Ghana J Agric Sci. 6:33-42.

Sennhenn A, Gebauer J, Omari F, Rohde E and Kehlenbeck K (2011) Electronic Document Delivery - Classification of Local Mango Varieties in Kenya by Using a Morphological Characterization and Identification Approach, Tropentag, October 5-7, Bonn. www.tropentag.de/2011/abstracts/links/ Sennhenn_JYvwQmhb.pdf Accessed on 09/08/2013.

Sennhenn A, Prinz K, Gebauer J, Whitebread A, Jamnadass R Kehlenbeck K (2014) Identification of mango landraces from eastern and central Kenya using a morphological and molecular approach. Genet Resour Crop Ev. 61:7-22.

Singh LB (1960) The mango. Botany, Cultivation and Utilization. Interscience publishers INC., New York. pp 438.

Singh LB and Singh RN (1956) A Monograph on the Mangoes of UP. Superintendent of Printing, Uttar Pradesh Government, Lucknow, India. pp 144.

Subedi A, Bajracharya J, Joshi BK, Regmi HN, Gupta SR, Hari BCK (2005) Characterization and genetic diversity of mango (Mangifera indica L.) in Nepal. In: Sthapit BR, Upadhyay MP, Shrestha PK, Jarvis DI (eds.). On-farm conservation of agricultural biodiversity in Nepal. Volume I. Assessing the amount and distribution of genetic diversity on-farm. Proceedings of the Second National Workshop, 25- 27 Aug 2004, Nagarkot, Nepal. International Plant Genetic Resources Institute, Rome, Italy, pp. 167-175.

Toili MEM, Rimberia FK, Nyende AB, Mutwiwa U, Kaluli J, Sila D (2013) Electronic Document Delivery- Assessing morphological diversity of mango germplasm from upper 
Athi river (UAR) region of eastern Kenya. www. elearning. jkuat.ac.ke/ journals/ ojs/ index.php/jscp/article/viewFile Accessed on 09/08/2013.

Uddin MZ, Rahim MA, Barman JC Wadud MA (2006) A study on the physical characteristics of some mango germplasm grown in Mymensingh condition. Int J Sustain Crop Prod. 1(2): 33-38.
Uddin MZ, Mortuza MG, Alam MA, Islam MS Uddin MS (2007). Performance of some commercial and promising mango varieties. J Bangladesh Soc Agric Sci Technol. 4 (1\&2): 105-108.

Watson BJ, Winston EC (1984). Plant genetic improvement. In: Proceedings of the First Australian Mango Research Workshop. Commonwealth Scientific and Industrial Research Organization (CSIRO), Queensland, 104-138. 